\title{
Median Ventricular Rate by Electrocardiogram
}

National Cancer Institute

\section{Source}

National Cancer Institute. Median Ventricular Rate by Electrocardiogram. NCI Thesaurus. Code C119261.

An assessment of the median ventricular depolarization rate as measured and recorded by an electrocardiograph during a specified period of time, and which is usually expressed in beats per minute. 